\title{
EFFECT OF NPK FERTILIZER ON FRUIT YIELD AND YIELD COMPONENTS OF PUMPKIN (Cucurbita pepo Linn.)
}

Oloyede FM$^{1 *}$, Agbaje GO ${ }^{1}$ and IO Obisesan ${ }^{1}$

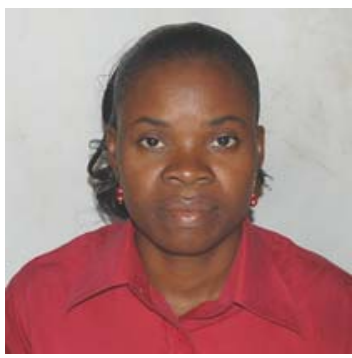

Funmilayo Oloyede

*Corresponding author email: funmilayooloyede@yahoo.co.uk

${ }^{1}$ Department of Crop Production and Protection Obafemi Awolowo University Ile-Ife, Nigeria. 


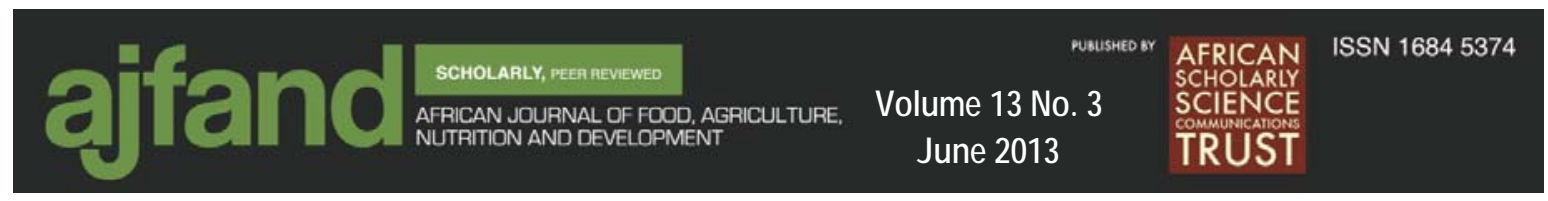

\section{ABSTRACT}

Pumpkin (Cucurbita pepo Linn.) is a vegetable crop often grown without fertilizer by peasant farmers in Nigeria. With the increased pressure on land resources for other competing uses, farmers have adopted the use of fertilizers to boost crop productivity. This study was carried out for the purpose of evaluating the influence of NPK fertilizer on fruit yield and fruit yield parameters of pumpkin. The experiment was carried out under open field conditions in 2010 for two seasons at the Teaching and Research Farm, Obafemi Awolowo University, Ile-Ife, Nigeria. The farm is located on latitude $07^{\circ} 28^{\prime} \mathrm{N}$ and longitude $04^{\circ} 33^{\prime} \mathrm{E}$ about $244-\mathrm{m}$ above sea level. NPK 15:15:15 compound fertilizer was applied as ring/side dressing at the rates of $(0,50$, 100, 150, 200, $250 \mathrm{~kg} / \mathrm{ha}$ ). The experiment was a randomized complete block design and was replicated six times. Each plot size was $10 \mathrm{~m} \mathrm{X} 12 \mathrm{~m}$ and consisted of 7 rows. Alley was $3 \mathrm{~m}$, while the plants were spaced $2 \mathrm{~m} \times 2 \mathrm{~m}$. Data were taken on yield and yield parameters such as: fruit height, fruit circumference, fruit fresh weight, fruit dry matter, fruit yield, seed number and seed weight. The fresh fruit yield was $21 \mathrm{t} / \mathrm{ha}$ and $7 \mathrm{t} / /$ ha for early and late seasons, respectively. Fruits number/ha significantly $(\mathrm{p}=0.05)$ increased from 7000 in control to over 10,000/ha at fertilizer rates between 100 and $250 \mathrm{~kg} \mathrm{NPK} / \mathrm{ha}$. Fruit weight also increased from 9 to 17t/ha between control and higher fertilizer rates. Seed yield from the application at 100 to $250 \mathrm{~kg} / \mathrm{ha}$ were similar and significantly better than control and $50 \mathrm{~kg} / \mathrm{ha}$ NPK application. Mean seed yield between 100-250 kg NPK was $460 \mathrm{~kg} / \mathrm{ha}$. The value was $37 \%$ higher than at 50 $\mathrm{kg}$ NPK and 57\% higher than in control. Increasing fertilizer above $100 \mathrm{~kg}$ NPK/ha did not significantly $(\mathrm{p}=0.05)$ increase the fruit yield nor the seed yield.

Key words: NPK fertilizer, Fruit yield, Pumpkin 


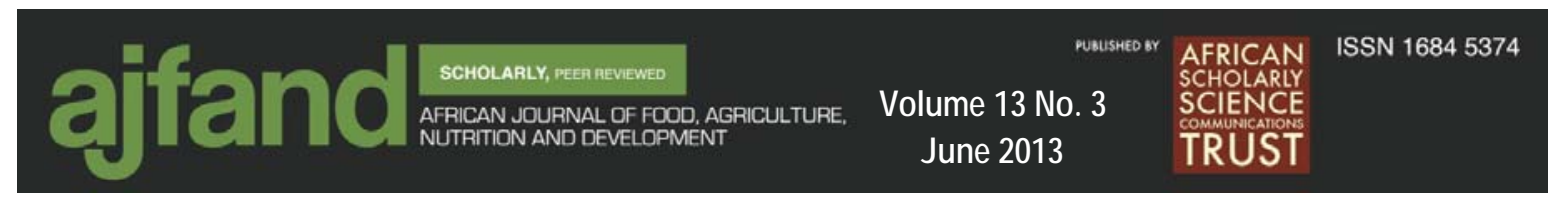

\section{INTRODUCTION}

Pumpkin fruits are rich in carotenoids, minerals and vitamins. Recent studies have shown that they are a veritable source of antioxidants. Antioxidants are required to boost the human body immunity against cancer and other deadly human diseases. Pumpkin is cultivated and consumed widely among the rural dwellers in southwest Nigeria where the mature fruits serve as food security during the dry season because of its long shelf-life.

With the increasing pressure on farm land for infrastructure development, limited land is available for this crop that requires large expanse of area for its cultivation. Pumpkin vines can spread beyond 15 meters from its stand and covers the land within 45 days of planting [1]. Hence, due to limited land resource, farmers now plant this crop on intensively cultivated lands. This practice has implication on the yield of the crop and expansion of its production. The plant is harvested at intervals for young foliage and emerging young fruits, this influences the nutrient mining of the soil. Farmers now use fertilizer to improve the yield of the crop due to its serial harvesting and the use of depleted soils.

Soil fertilization is one of the main factors increasing the yield of plants [2]. It affects the accumulation, mineralization and humification of organic matter added to the soil [3], and determines plant production potential [4]. The amount of fertilizer introduced into the soil, including mineral fertilizers affects the amount of mineral nitrogen available to the plants and the organic carbon content of the soil [5].

Siyag and Arora [6], on their studies on the effect of Nitrogen (N) and Phosphorus (P) on fruit yield and quality of sponge gourd (Luffa aegyptiaca) reported that $50 \mathrm{Kg} \mathrm{N}+$ $20 \mathrm{Kg} \mathrm{P} \mathrm{ha}{ }^{-1}$ gave the maximum number of fruits and the greatest weight/plant. It has been studied that Potassium $(\mathrm{K})$ in different forms positively influenced the plant yield and its chlorophyll contents [7]. Mobile phosphorus and potassium have also been reported to be important for the setting, development and storage of pumpkin fruits [8]. In the studies of effect of organic and mineral fertilization on yield and quality of C. pepo in Italy, using $250 \mathrm{~kg} \mathrm{~N}, 280 \mathrm{~kg} \mathrm{P}_{2} \mathrm{O}_{5}$ and $250 \mathrm{~kg} \mathrm{~K}_{2} \mathrm{O}$ per hectare as one of the treatments, it was discovered that NPK fertilization markedly influenced yield and quality of pumpkin. In another study, $500 \mathrm{~kg} / \mathrm{ha}$ of $\mathrm{N}$ : P: $\mathrm{K}-10: 10: 20$ was used as a treatment. Fertilization rate at the level of $500-700 \mathrm{~kg} /$ ha is recommended for Pumpkins in the temperate region [8, 9].

Information on fertilizer requirement for $C$. pepo in Southwestern Nigeria is scanty. It was reported by Martinetti and Paganini [10] that NPK fertilization markedly influenced yield and quality of pumpkin. The three major fertilizer elements known to be deficient in most Nigerian soils due to intense pressure on land as a result of continuous cropping are N, P and K. [11]. In the tropics, especially in Nigeria, there is no documented knowledge on NPK fertilizer requirement for yield of C. pepo. This

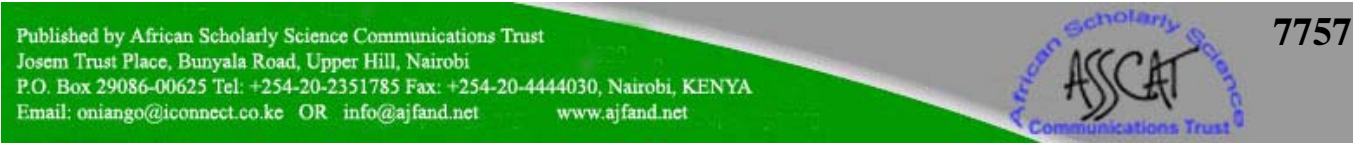




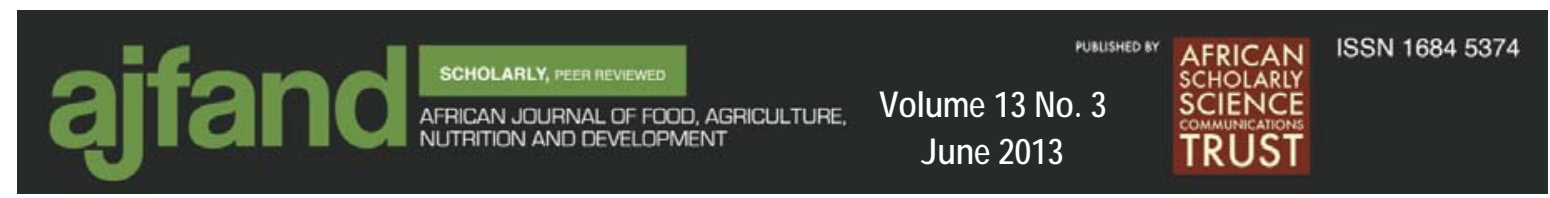

study thus aimed at evaluating the effect of NPK fertilizer on the fruit yield of $C$. реро.

\section{MATERIALS AND METHODS}

Field experiment was carried out during the early cropping season (May to August) and late cropping season (August to November) of 2010, at the Teaching and Research Farm, Obafemi Awolowo University, Ile-Ife, Nigeria. The experiment commenced on the 17th of May by planting two seeds of pumpkin at a spacing of $2 \mathrm{~m}$ by $2 \mathrm{~m}$ and later thinned after two weeks to one seedling per stand to give a population of 42 plants per plot and 2,500 plants per ha, plot size being $10 \mathrm{~m}$ by $12 \mathrm{~m}$. The treatments used were NPK fertilizer 15:15:15 fertilizer rates at 0, 50, 100, 150, 200, $250 \mathrm{~kg} / \mathrm{ha}$. The experiment was laid out in a randomized complete block design (RCBD) with six replicates. The NPK fertilizer was added in two equal halves at 2 weeks after planting (WAP) and 6 WAP. Insecticide (lambda-cyhalothrin) was applied fortnightly from 6 to 10 WAP. Post-emergence herbicide, glyphosate was applied at the rate of $200 \mathrm{ml} /$ 15litre at 4 and $7 \mathrm{WAP}$ for weed control.

Data were recorded from 4 rows in the plot for the number of fruits, fresh fruit weight, fruit height, fruit girth and fruit dry matter. Fruit height and fruit girth were measured using a metre rule. Seed weight and number of seeds per fruit were also recorded. The fruit weight and number of fruits per plot determined the fruit yield per plot. Fruit yield was calculated thus:

$$
\text { Fruit yield (tons /ha) }=\frac{\text { fruit weight } / \text { plot }(\mathrm{kg}) \times 10,000 \mathrm{~m}^{2}}{\text { Area of plot }\left(\mathrm{m}^{2}\right) \times 1,000 \mathrm{~kg}}
$$

All data were subjected to combined analysis of variance [12]. Means squares, where significantly different, were separated using Duncan Multiple Range Test (DMRT) at $5 \%$ level of probability. Regression analysis was performed for traits that had significant seasons and fertilizer mean squares.

\section{RESULTS}

\section{Fruit yield and yield components as influenced by NPK fertilizer}

Table 1 showed that the mean square $\left(\mathrm{MS}^{2}\right)$ contribution of fertilizer to variations in yield and yield components was significant except in number of seeds per fruit. The $\mathrm{MS}^{2}$ percentage contribution of fertilizer was higher than that of the season $\mathrm{x}$ fertilizer interactions in all the traits measured and especially in fruit dry weight (g/plant) and 100 seed weight when compared with seasons effect.

Fertilizer influence on the whole fruit parameters in Table 2 showed that the application of NPK fertilizer at rates above $100 \mathrm{~kg} / \mathrm{ha}$ will not significantly increase the harvested number of fruits, fruit fresh and dry weights, fruit length or circumference. There were significant differences in the traits measured between the

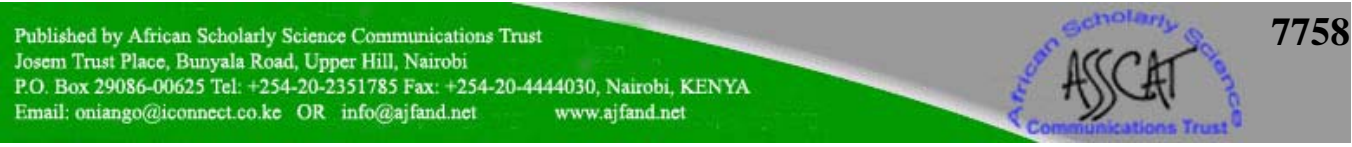




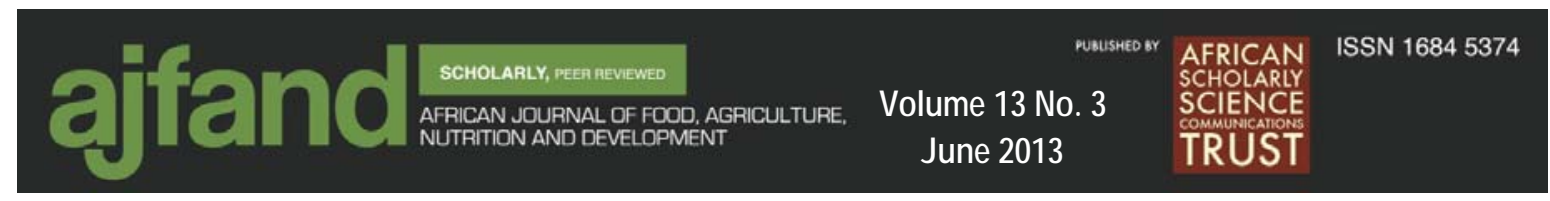

control and $100 \mathrm{~kg}$ NPK fertilizer rates. In the same traits, the application of $250 \mathrm{Kg}$ NPK does not confer any advantage when compared with that at $100 \mathrm{~kg}$ NPK rate. For example, mean fruit number between 100-250 kg NPK was 11795 per hectare. The value was $22 \%$ higher than at $50 \mathrm{~kg}$ NPK and $40 \%$ higher than in control. Mean fruit yield between 100-250 kg NPK was 16.18 tons/ha. The value was $28 \%$ higher than at $50 \mathrm{~kg}$ NPK and 44\% higher than in control. Mean fruit dry matter between $100-250 \mathrm{~kg}$ NPK was $441.2 \mathrm{~g} /$ fruit. The value was $29 \%$ higher than at $50 \mathrm{~kg}$ NPK and $44 \%$ higher than in control. Mean fruit length between 100-250 kg NPK was $17 \mathrm{~cm} /$ fruit. The value was $14 \%$ higher than at $50 \mathrm{~kg}$ NPK and $16 \%$ higher than in control. Mean fruit circumference between 100-250 kg NPK was $53 \mathrm{~cm} /$ fruit. The value was $12 \%$ higher than at $50 \mathrm{~kg}$ NPK and 16\% higher than in control.

Table 3 shows that numbers of seeds per fruit were similar between the fertilizer rates and it ranged from 336 to 356. Although, seed yield increased with fertilizer rates, seed yield from the application at 100 to $250 \mathrm{~kg} / \mathrm{ha}$ were similar and performed better $(\mathrm{p}=0.05$ ) than the control and $50 \mathrm{~kg} / \mathrm{ha}$ NPK application rate. Mean seed yield between 100-250 kg NPK was $460 \mathrm{~kg} / \mathrm{ha}$. The value was 37\% higher than at $50 \mathrm{~kg}$ NPK and 57\% higher than in control. Number of seeds per fruit was not influenced by fertilizer. Seeds/fruit range from 337 to 356 at different fertilizer rates and between seasons it was 329 to 362 . Fertilizer improved the 100 seeds weight significantly. The control had the lowest seed weight (99.5 g/100g seed) while the application of 100$250 \mathrm{~kg}$ NPK increased seed weight to between 100.2 and 100.4.

\section{Interactive effect of season and fertilizer on some yield and yield traits}

Figure 1 shows that fruit number was higher across the fertilizer levels in the early season than in the late season. The response of fruit number fitted into quadratic equation with $\mathrm{R}^{2}$ ranging from 0.88 to 0.93 . Fruit number generally increased from the control to reach the optimum number of 15750 and 7000 per hectare for early and late seasons respectively at $200 \mathrm{~kg} / \mathrm{ha}$ of NPK (15:15:15) fertilizer application. The fruit number in control ranges from 5000 to 10000 /ha.

Figure 2 shows that fruit yield was higher across the fertilizer levels in the early season than in the late season. The response of fruit yield fitted into quadratic equation with $\mathrm{R}^{2}$ ranging from 0.83 to 0.94 . Fruit yield generally increased from the control (zero fertilizer) to reach the optimum yield of 24 and 9 tons/ha.

Figure 3 shows that fruit circumference was higher across the fertilizer levels in the early season than in the late season. The response of fruit circumference fitted into a quadratic equation with $\mathrm{R}^{2}$ ranging from 0.83 to 0.91 . Fruit circumference generally increased from the control (zero fertilizer) to reach the optimum circumference of 57 $\mathrm{cm}$ and $47 \mathrm{~cm}$ for early and late seasons respectively at $200 \mathrm{~kg} / \mathrm{ha}$ of NPK (15:15:15) fertilizer application.

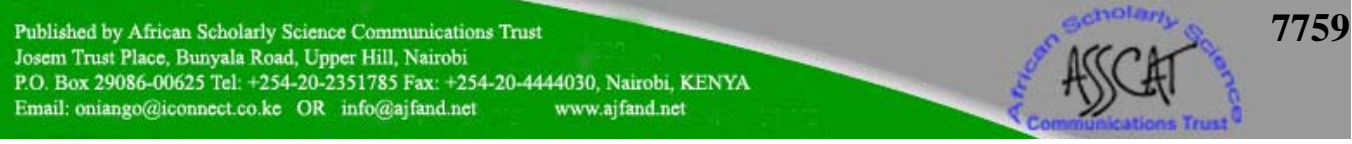




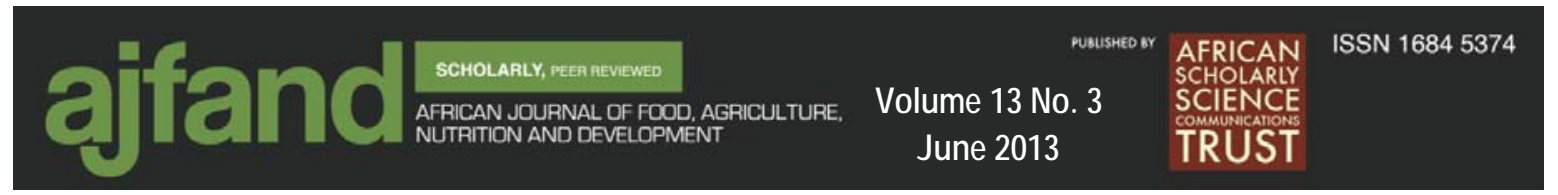

Figure 4 shows that seed yield was higher across the fertilizer levels in the early season than in the late season. The response of seed yield fitted into quadratic equation with significant $\mathrm{R}^{2}$ ranging from 0.87 to 0.91 . Seed yield generally increased from the control (zero fertilizer) to reach the optimum yield of 690 and $230 \mathrm{~kg} / \mathrm{ha}$ for early and late seasons respectively at $200 \mathrm{~kg} / \mathrm{ha}$ of NPK (15:15:15) fertilizer application. The values are similar to those of 100, 150 and $250 \mathrm{~kg} / \mathrm{ha}$ of NPK per hectare.

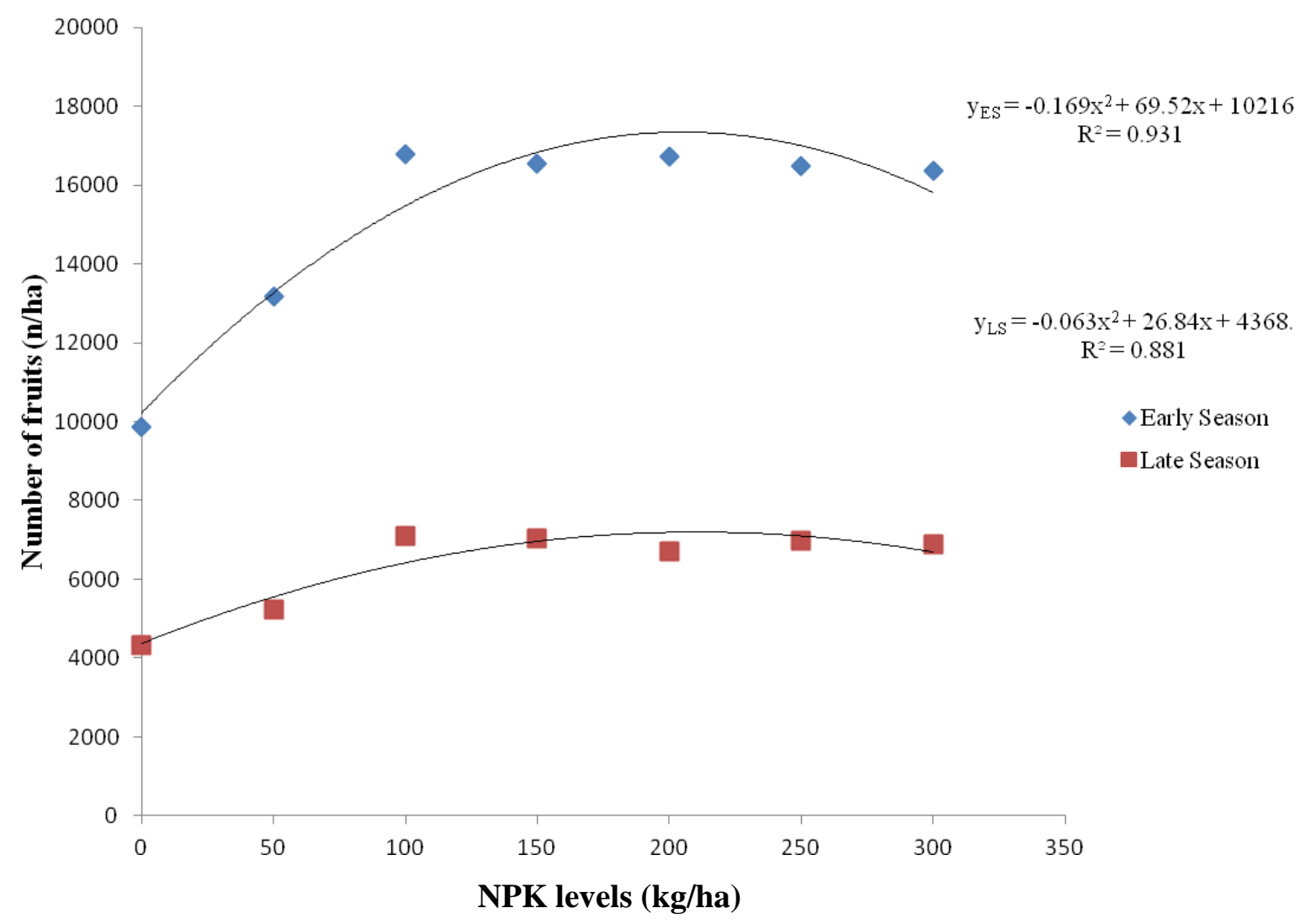

Figure 1: Number of fruits as affected by Season $x$ NPK fertilizer 

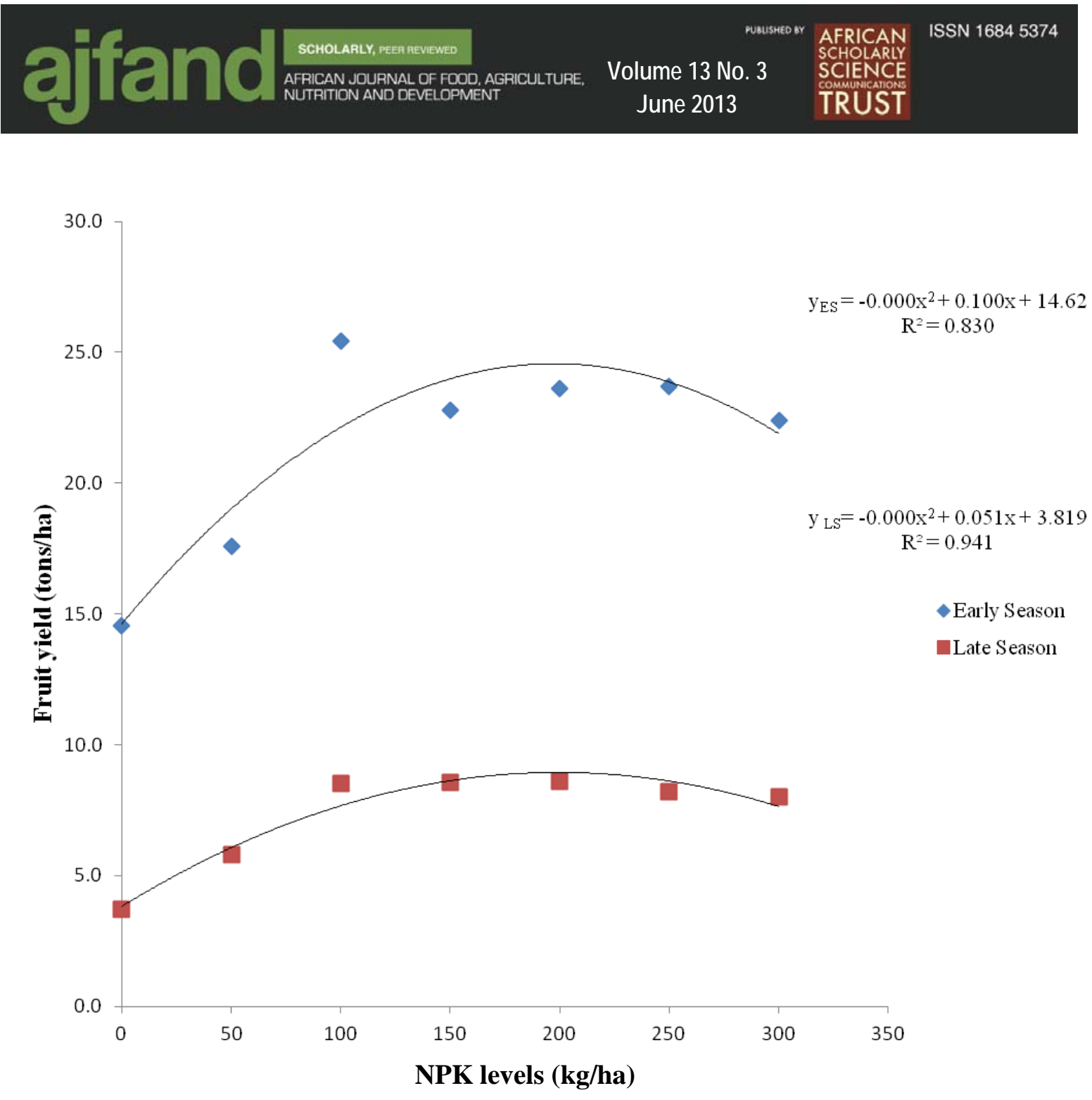

Figure 2: Fruit yield of pumpkins as affected by Season $x$ NPK fertilizer 

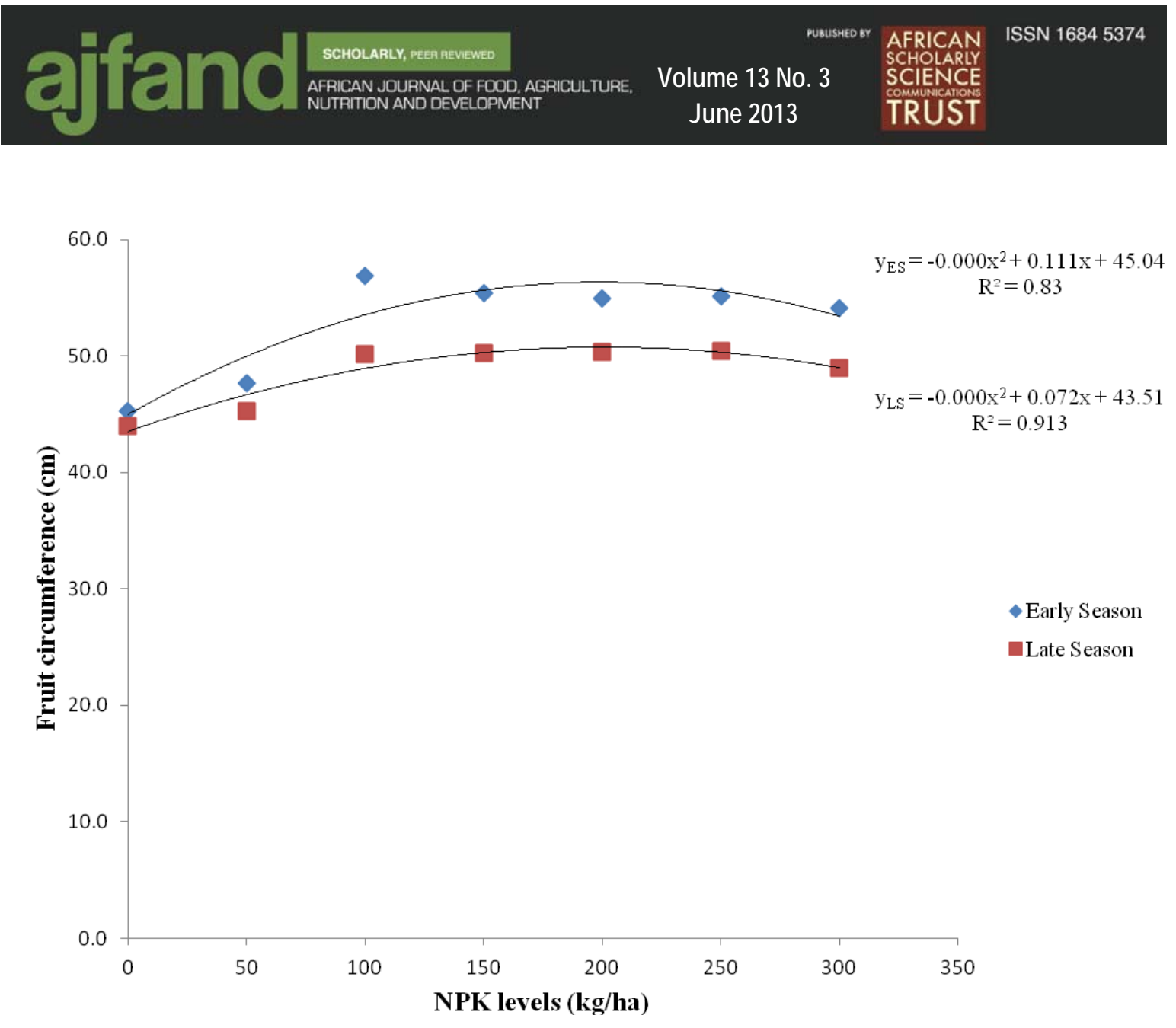

Figure 3: Fruit circumference as affected by Season $x$ NPK fertilizer 

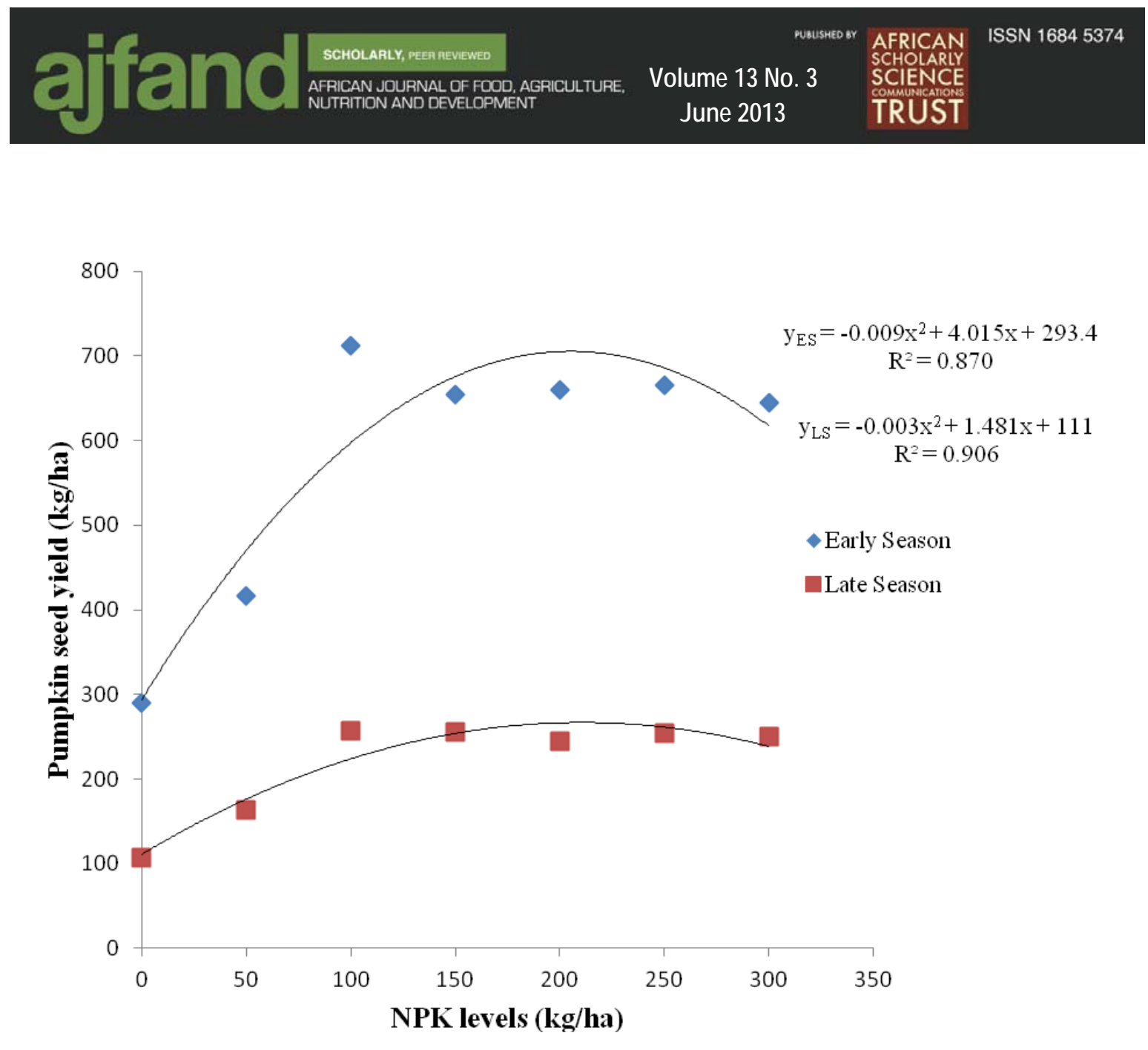

Figure 4: Pumpkin seed yield as affected by season $x$ NPK fertilizer

\section{DISCUSSION}

The dependence of fruits number in Cucurbits on radiation, season and fertility had earlier been reported [13, 14]. The findings of Adebooye and Oloyede [15] in their studies on Trichosanthes cucumerina L., a member of the same family (Cucurbitaceae) corroborate this study. They found that the number of marketable fruits and overall fruit yield increased to a certain level with Phosphorus fertilizer application. The optimum NPK level in this study was $100 \mathrm{~kg} / \mathrm{ha}$ where the fruit yield and its components were higher than all other levels. Beyond this level there was no additional significant effect of NPK on yield of C. pepo.

Fruit weight was higher with application of fertilizer; however, the addition of fertilizer beyond $100 \mathrm{~kg} / \mathrm{ha}$ did not increase fruit yield significantly. There was a depression of fruit number and fruit weight in a study on pumpkin in Lithuania due to increased fertilizer and this agreed with this study $[10,16]$. Although due to different climatic conditions, soil type and soil native nutrient, NPK recommendations for optimum fruit yield may be as high as $250-500 \mathrm{~kg}$ NPK/ha; but in this study 100

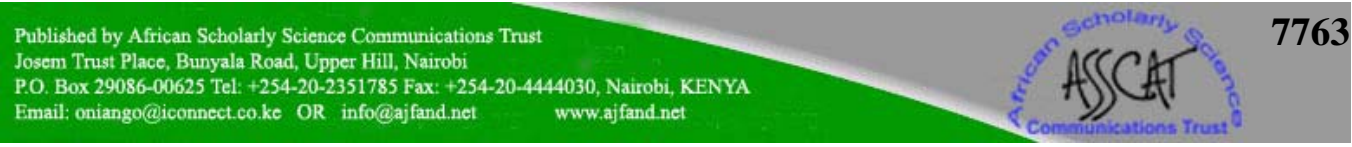


kg/ha of NPK fertilizer was adequate. Hossain et al., [17] and Kraup et al. [18] even recommended a lower rate of nitrogen ( $50 \mathrm{~kg} \mathrm{~N} / \mathrm{ha}$ ) for optimum yield performance in pumpkin. Paschold et al. [19] reported that excessive nitrogen supply produced less vigorous spears of Asparagus, while nitrogen deficiency reduced Asparagus quality. Heavy application of phosphorous has been found also to depress the fruit yield of tomato fruits [20]. Oloyede and Adebooye [13] also found out that there was reduction in fruit yield of snake tomato (Trichosanthes cucumerina L.), which belongs to the same family Cucurbitaceae as the concentration of phosphorous application increased.

Fruit yield per hectare in cucumber was found to be influenced positively by the application of lower concentrations of maleic hydrazide, either alone or in combination with ethephon [21, 22]. A similar trend was observed by Bhat et al. [23] who reported maximum fruit yield in watermelon with an application of maleic hydrazide at $100 \mathrm{ppm}$. The yield increased from 7.22 tons/ha in the control to 13.1 tons/ha in the treatment with $100 \mathrm{ppm}$ maleic hydrazide and $100 \mathrm{ppm}$ ethephon, resulting in an additional return which increased the income from treated plots. The high return was clearly due to the maximum fruit yield per hectare in the treatment.

Seeds form a major part of the diet of Nigerians and Africans as a whole. Pumpkin seeds are used alone as food thickeners or in combination with leafy vegetables [24]. The seeds are a good raw material for the production of oil used in food preparation and in medicine [25]. According to Oloyede et al. [24], the seeds contain about $60 \%$ fats, $27 \%$ protein and $90 \%$ antioxidant activities when moderate fertilizer is applied. Oil-cake fats from pumpkin seeds have been found also to contain large amounts (almost 60\%) of omega-3 acids which is twice that of cod liver oil [26].

Seed yield of pumpkin is directly proportional to the size of its fruits. At $100-250 \mathrm{~kg}$ $\mathrm{NPK} / \mathrm{ha}$ seed yield obtained were higher compared to the control and at $50 \mathrm{~kg}$ NPK/ha. The heavier the fruit the higher the seed yield per hectare. This is of great advantage when the crop is being cultivated for seeds. However, neither seasons nor fertilizer application had influence on the number of seeds per fruit. This means that the trait is genetic. Ekpedeme et al. [27] had reported an average seed yield of 2-4 t/ha in pumpkin. In this experiment, the application of $100 \mathrm{~kg} / \mathrm{ha}$ of NPK 15:15:15 fertilizer yielded, $700 \mathrm{~kg} / \mathrm{ha}$ and $300 \mathrm{~kg} / \mathrm{ha}$ of seeds for early and late seasons, respectively. This showed that the potential seed yield of pumpkin needs to be enhanced by looking into other areas of agronomy and physiology of the crop or in breeding the crop for higher seed yield in rainforest ecology.

\section{CONCLUSION}

Fruit and seed yield of pumpkin was optimal at $100 \mathrm{~kg} / \mathrm{ha}$, the number and the size of fruits were higher at this rate than other NPK levels. This, therefore, suggests that 100 $\mathrm{kg} / \mathrm{ha}$ NPK fertilizer rate is the optimum NPK level for C. pepo at the location where

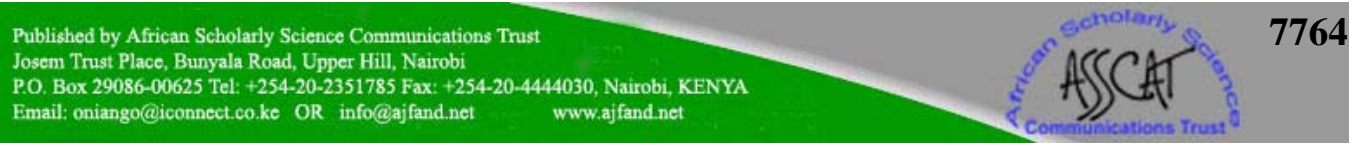




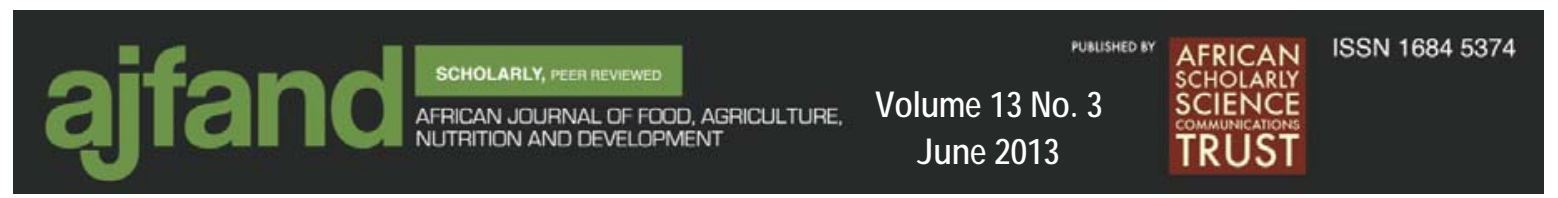

this experiment was conducted. This indigenous fruit vegetable if harnessed has potential to reduce hunger, alleviate poverty and enhance food and nutrition security.

Pumpkin fruit has been found to be rich in carbohydrate, protein and antioxidant activities. It is not as bulky as yam and as a result comparable to Irish potato and can be used as breakfast. Moreover, the production is less labour intensive and more profitable compared to yam and many other staples. For instance, $2 \mathrm{~kg}$ of pumpkin fruit cost $\$ 1$ in Nigeria. If fertilizer is not used, 9.1 tons/ha will be produced, the value of crop will cost $\$ 4,550$. Assuming every other variables are fixed; $100 \mathrm{~kg} / \mathrm{ha}$ fertilizer application cost $\$ 125$. At this optimal fertilizer level, 17 tons of fruit is produced, this will be sold for $\$ 8,500$. If the cost of fertilizer is deducted, $\$ 8,375$ will be left. Hence, fertilizer application at $100 \mathrm{~kg} / \mathrm{ha}$ can increase the profit of pumpkin production by approximately $100 \%$.

Further studies on the improvement of this useful but underutilized crop are a worthwhile effort to broaden the food base and widen the income base of the African populace. 


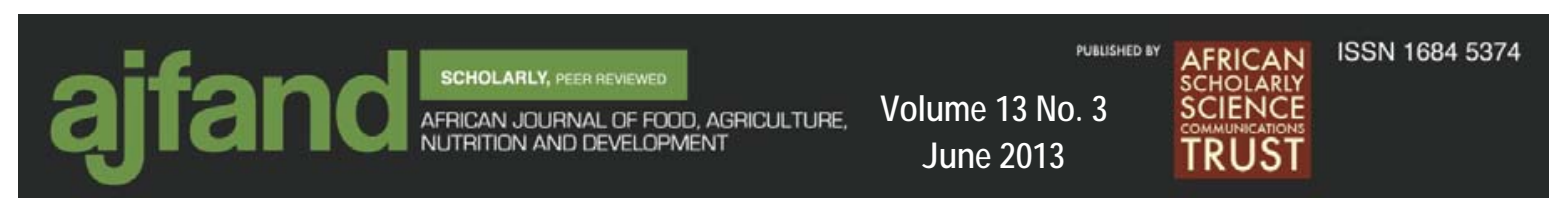

Table 1: Means Squares from the combined analysis of variance for fruit yield and yield components of pumpkin

\begin{tabular}{|c|c|c|c|c|c|c|c|c|c|}
\hline Source & DF & $\begin{array}{l}\text { No of fruits/ha } \\
\text { (n) }\end{array}$ & $\begin{array}{l}\text { Fruit } \\
\text { weight } \\
\text { (kg/ha) }\end{array}$ & $\begin{array}{l}\text { Fruit } \\
\text { length } \\
(\mathrm{cm}) \\
\end{array}$ & $\begin{array}{l}\text { Fruit } \\
\text { circumference } \\
(\mathrm{cm}) \\
\end{array}$ & $\begin{array}{l}\text { Fruit dry } \\
\text { matter } \\
\text { (g/fruit) }\end{array}$ & $\begin{array}{l}\text { No of } \\
\text { seed/fruit } \\
\text { (n) }\end{array}$ & $\begin{array}{l}100 \text { seeds } \\
\text { weight }(\mathrm{g})\end{array}$ & $\begin{array}{l}\text { Seed yield } \\
(\mathrm{kg} / \mathrm{ha})\end{array}$ \\
\hline Season & 1 & $1361767578^{* *}$ & $3553.95 * *$ & $20.69 * *$ & $310.83 * *$ & $7854^{*}$ & 19933 & 19110 & $2199321^{* *}$ \\
\hline Rep within season & 10 & 4551953 & 4.71 & 1.01 & 5.96 & 1208 & 3124 & 932 & 13496 \\
\hline Fertilizer & 5 & $47981641^{* *}$ & $116.52^{* *}$ & $20.67 * *$ & $180.31^{* *}$ & $87626^{* *}$ & 1223 & $29006 * *$ & $161399 * *$ \\
\hline Season*Fertilizer & 5 & $8837891^{* *}$ & $15.81^{*}$ & 0.67 & $11.61^{* *}$ & 540 & 2664 & 1085 & $33955 * *$ \\
\hline Pooled error & 50 & 1340078 & 5.36 & 0.46 & 3.13 & 418 & 2430 & 702 & 35100 \\
\hline CV (\%) & & 10.9 & 16.2 & 4.2 & 3.5 & 5.3 & 14.3 & 7.5 & 15.4 \\
\hline
\end{tabular}

\footnotetext{
* = significant at 0.05 level of probability

** = significant at 0.01 level of probability
}

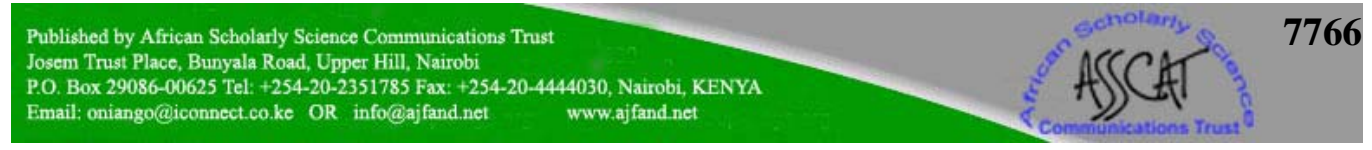




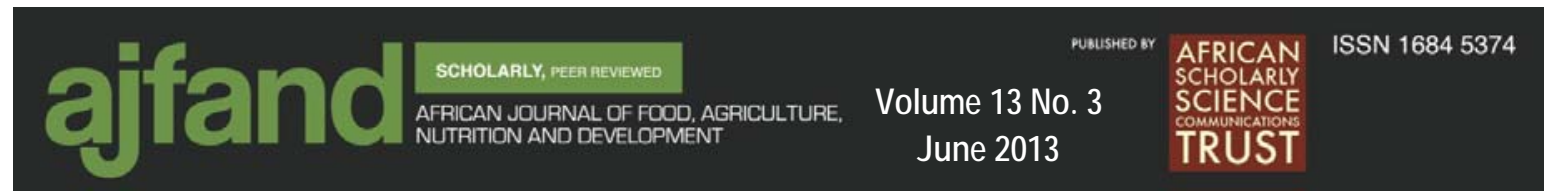

Table 2: Fruit yield and yield parameters of pumpkin as influenced by NPK fertilizer

\begin{tabular}{|c|c|c|c|c|c|}
\hline $\begin{array}{l}\text { NPK level } \\
\text { (kg/ha) }\end{array}$ & $\begin{array}{c}\text { Fruit number } \\
\text { (n/ha) }\end{array}$ & $\begin{array}{c}\text { Fruit Dry } \\
\text { matter } \\
\text { /fruit (g) }\end{array}$ & $\begin{array}{c}\text { Fruit weight } \\
\text { (tons/ha) }\end{array}$ & $\begin{array}{l}\text { Fruit length } \\
(\mathrm{cm})\end{array}$ & $\begin{array}{c}\text { Fruit } \\
\text { circumference } \\
\text { (cm) }\end{array}$ \\
\hline control & $7094 c$ & $248.5 c$ & $9.13 c$ & $14.3 b$ & $44.6 \mathrm{c}$ \\
\hline 50 & 9198b & $312.4 \mathrm{~b}$ & $11.70 \mathrm{~b}$ & $14.7 \mathrm{~b}$ & $46.5 b$ \\
\hline 100 & 11938a & $438.5 a$ & $16.97 a$ & $17.1 \mathrm{a}$ & $53.6 \mathrm{a}$ \\
\hline 150 & $11792 \mathrm{a}$ & $437.8 \mathrm{a}$ & $15.67 \mathrm{a}$ & $16.8 \mathrm{a}$ & $52.8 \mathrm{a}$ \\
\hline 200 & 11719a & $444.0 \mathrm{a}$ & $16.10 \mathrm{a}$ & $17.0 \mathrm{a}$ & $52.6 \mathrm{a}$ \\
\hline 250 & 11729a & $444.5 a$ & $15.97 \mathrm{a}$ & $17.2 \mathrm{a}$ & $52.8 \mathrm{a}$ \\
\hline
\end{tabular}

Means with the same letter in each column are not significantly different at 5\% level of Probability using Duncan's Multiple range test 


ajfand

Table 3: Seed yield of Pumpkin as influenced by NPK fertilizer

\begin{tabular}{cccc}
\hline $\begin{array}{c}\text { NPK level } \\
\text { (kg/ha) }\end{array}$ & No of seeds/fruit & $\mathbf{1 0 0}$ seeds weight (g) & Seed yield (kg/ha) \\
\hline control & $337 \mathrm{a}$ & $9.95 \mathrm{c}$ & $199 \mathrm{c}$ \\
50 & $334 \mathrm{a}$ & $9.99 \mathrm{~b}$ & $290 \mathrm{~b}$ \\
100 & $353 \mathrm{a}$ & $10.02 \mathrm{a}$ & $484 \mathrm{a}$ \\
150 & $337 \mathrm{a}$ & $10.03 \mathrm{a}$ & $455 \mathrm{a}$ \\
200 & & & $442 \mathrm{a}$ \\
& $353 \mathrm{a}$ & $10.04 \mathrm{a}$ & $460 \mathrm{a}$ \\
& & & \\
& $356 \mathrm{a}$ & $10.04 \mathrm{a}$ & \\
& & &
\end{tabular}

Means with the same letter in each column are not significantly different at 5\% level of Probability using Duncan's multiple range test. 


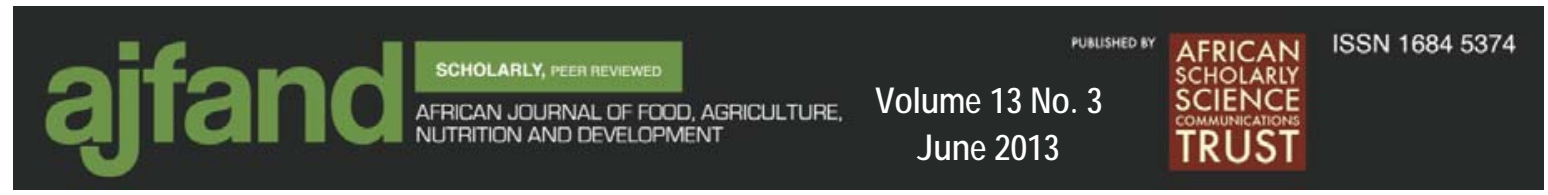

\section{REFERENCES}

1. Oloyede F M Agronomic traits and Nutritional values of pumpkin (Cucurbita pepo Linn.) as influenced by NPK fertilizer. An unpublished Ph.D. Thesis submitted to the Department of Plant Science, Obafemi Awolowo University, Ile-Ife, Nigeria. 2011.

2. Kolodziej B Effect of mineral fertilization on ribwort plantain (Plantago lanceolata L.) yielding (in Polish). Acta Agrophysica. 2006; 141: 637-647.

3. Loginow W, Andrzejewski $\mathbf{J}$ and $\mathbf{J}$ Janowiak Role of organic fertilization in maintenance of stock of organic stuff in soil (in Polish). Roczn.Glebozn. 1991; 42 (3/4): 19-25.

4. Demmler D Grundungung zur Stabilisierung der Bodenfruchtbarkeit bzw. Zur Verringerung von N-Verlusten. Kartoffelbau. 1998; 49(6): 232-235.

5. Bijlsma RJ and $\mathbf{H}$ Lambers A dynamic whole-plant model of integrated metabolism of nitrogen and carbon. Plant and Soil. 2000; 220: 71-87.

6. Siyag S and SK Arora Effect of Nitrogen and phosphorus on fruit yield and quality of sponge gourd (Luffa aegyptiaca). Indian Journal of Agricultural Sciences. 1988; 58: 860-861.

7. Chapagain BP and Z Wiesman Effect of potassium magnesium chloride in the fertigation solution as partial source of potassium on growth, yield and quantity of greenhouse tomato. Hort. Sci. 2004; 99 (3-4): 279-288.

8. MacCarthy CE and RL Clapp Humic substances in soil and crop sciences: selected readings. Am. Soc. of Agron. Madison,Wiscosin. 1990.

9. Paulauskiene A, Danilcenko $\mathbf{H}$, Rutkoviene $\mathbf{V}$ and $\mathbf{J}$ Kulaitiene The influence of various fertilizers on electrochemical properties of pumpkin fruits. Lietuvos sodininkystes ir darzininkystes inst., LZUU. 2005; 24(3): 78-86.

10. Martinetti $\mathbf{L}$ and $\mathbf{F}$ Paganini Effect of organic and mineral fertilization on yield and quality of zucchini. Acta Hort. 2006; 700:125-128.

11. Aduayi EA, Chude VO, Adebusuyi BA and SO Olayiwola Fertilizer use and management practices for crops in Nigeria. Federal Fertilizer Department, Federal Ministry of Agriculture and Rural Development, Abuja Nigeria. 2002; Pp16.

12. SAS (Statistical Analysis System) Version 9.1. SAS Institute Inc., Cary, NC. 2003. 
13. Oloyede FM and OC Adebooye Effect of season on growth, fruit yield and nutrient profile of two landraces of Tricosanthes cucumerina L. African Journal of Biotechnology. Kenya. 2005; 4(6): 1040-1044.

14. Konova $\mathbf{L}$ and $\mathbf{L}$ Rainova Chemical composition of soybean seed. In Arabadshier CD, Batashki A Goranora (eds) soyabeans. Soyabean, Moscow. 1981; Pp. 42-54.

15. Adebooye OC and FM Oloyede Effect of phosphorus on the fruit yield and food value of two landraces of Trichosanthes cucumerina L.- Cucurbitaceae, Food Chemistry, UK. 2005;100: 1259-1264.

16. Al-Mukhtar FA, Hummadi FM and FH Al-Sahaf Effect of different levels of NPK fertilizer on growth and yield of two summer squash cultivars. Acta Horticulturae. 1987; 200:253-258.

17. Hossain KL, Rahman M, Banu MA, Khan TR and MS Ali Nitrogen Fertilizer effects on the Agronomic aspects of Asparagus racemosus. Asi. J. Plant Sci. 2006; 5 (6): 1012-1016.

18. Kraup C, Kraup A, Pertierra R and A Uragami Growth of Asparagus crowns with increasing nitrogen rates at three different sites. Proceedings of the 10th International Asparagus Symposium Niigata, Japan, 30 August to 2 September, 2001. Acta Horticulture, 2002; 589: 145-150.

19. Paschold PJ, Hermann G and B Artell Nitrogen, yields, spear quality and Nmin residues of Asparagus. Gemuse Munchen. 1999; 35: 588-592.

20. Winsor GW and MIE Long The effects of nitrogen, phosphorus, potassium, magnesium and lime in factorial combination on the size and shape of glass house tomatoes. Journal of Horticultural Science. 1968; 43: 322-334.

21. Singh RK and GP Singh Effect of growth regulators on sex expression, sex ratio and yield in cucumber (Cucumis sativus L.). Veg. Sci. 1984; 11: 15-20.

22. Mukesh T, Satesh $\mathbf{K}$ and $\mathbf{R}$ Rafiq Influence of plant growth regulators on morphological, floral and yield traits of cucumber (Cucumis sativus L.). 2011.

23. Bhat KL, Saleem T and A Bushan Effect of ethrel, maleic hydrazide and gibberellic acid on growth, yield and quality of watermelon (Citrullus lanatus Thumb.). Journal of Research, SKUAST-J. 2004; 2:221-227.

24. Oloyede FM, Obisesan IO, Agbaje GO and EM Obuotor Effect of NPK fertilizer on chemical composition of pumpkin (Cucurbita pepo Linn.) seeds. The Scientific World Journal, 2012; Article ID 808196, 6pages.

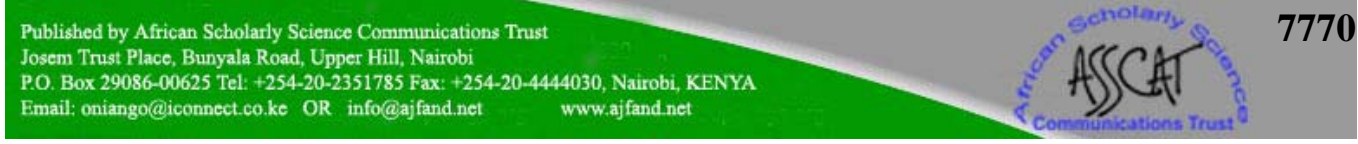




ajfand

25. Elmadfa I and D Fritzsche Tabele witamin I skladnikow mineralnych. Muza SA Warszawa, 1999; Pp. 39-96.

26. Jariene E, Danilcenko H, Kulaitiene J, Gajewski M and E Venskutoniene "Quality of oil bearing pumpkin cultivars depending on the fertilization method" in Spontaneous and Induced Variation for the Genetic Improvement of Horticultural Crops, Nowaczyk P. (ed.): University Press, University of Technology and Life Sciences, Bydgoszcz, Germany, 2007; Pp. 189-196.

27. Ekpedeme U, Akwaowo A and U Ekaete Minerals and antinutrients in fluted pumpkin. Food Chem. 2000; 70: 235-240. 